\title{
Our experience of laparoscopic partial adrenalectomy in surrenal adenomas
}

\section{Sürrenal adenomlarda laparoskopik parsiyel adrenalektomi deneyimimiz}

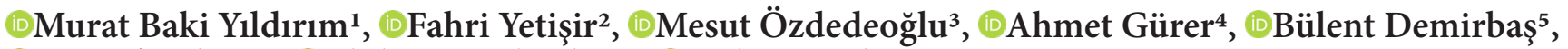 \\ ๑D Mustafa Aksoy ${ }^{6}$, ®Abdussamed Yalçın', ĐMehmet Kılınç \\ ${ }^{1}$ Hitit University, Faculty of Medicine, Department of General Surgery, Çorum, Turkey \\ ${ }^{2}$ VM Medical Park Ankara Hospital, Department of General Surgery, Ankara, Turkey \\ ${ }^{3}$ İstanbul Başaksehir Çam and Sakura City Hospital, Department of Gastrointestinal Surgery, İstanbul, Turkey \\ ${ }^{4}$ Ankara City Hospital, Department of General Surgery, Ankara, Turkey \\ ${ }^{5}$ Ankara Atatürk Training and Research Hospital, Department of General Surgery, Ankara, Turkey \\ ${ }^{6}$ Ankara Yildırım Beyazıt University, Department of Anesthesia, Ankara, Turkey \\ ${ }^{7}$ Ankara Yildırım Beyazıt University, Department of General Surgery, Ankara, Turkey \\ ${ }^{8}$ Eskişehir Osmangazi University, Department of General Surgery, Eskişehir, Turkey
}

Cite this article as/Bu makaleye atıf için: Yıldırım MB, Yetişir F, Özdedeoğlu M, et al. Our experience of laparoscopic partial adrenalectomy in surrenal adenomas. J Med Palliat Care 2021; 2(3): 71-76.

\begin{abstract}
Aim: For adrenal lesions which are functional and bigger than four centimeters, the optional therapy is surgery. Laparoscopy for the surgery of adrenal masses is increasingly used today. In the past, total adrenalectomy was performed for any adrenal lesions without any exception; however, bilateral involvement of tumors like pheochromocytoma causes trouble and forced surgeons to try partial adrenalectomy. Recently, partial adrenalectomy is a routine surgical procedure for bilateral lesions and also becoming common for unilateral lesions. We aimed to present short-term results for patients who undergo laparoscopic total or partial adrenalectomy.

Material and Method: We collect data retrospectively for 33 patients who were operated on in our clinic for adrenal mass between January 2010 and December 2014. 3 patients were excluded from the study. All data were gained from personal patient medical records. Follow-up records were noted with one-by-one interviews by questioning steroid usage and symptoms of adrenal insufficiency.

Results: Patients were divided into two groups as total adrenalectomy group with 19 patients and partial adrenalectomy group with 11 patients. All patients who underwent total adrenalectomy have unilateral lesions, while 4 for 11 partial adrenalectomy patients have bilateral adrenal masses. Adrenal insufficiency developed in 3 patients for total adrenalectomy, 1 patient for unilateral partial adrenalectomy, and 1 patient for bilateral partial adrenalectomy.

Conclusion: Partial adrenalectomy appears to be protective for adrenal insufficiency for bilateral cases with a ratio of $75 \%$. there was no significant difference between the total or partial unilateral adrenalectomy group, considering postoperative complications, recurrence rates, and insufficiency. As a result, laparoscopic partial adrenalectomy has similar results with less morbidity for unilateral lesions and an alternative method with less adrenal insufficiency for bilateral lesions. Laparoscopic partial adrenalectomy could be performed safely after the learning period was completed and should be considered for adrenal surgeries.
\end{abstract}

Keywords: Adrenalectomy, adrenal insufficiency, cortex sparing surgery, laparoscopy

\section{ÖZ}

Amaç: Adrenal kitleler fonksiyonel ve $4 \mathrm{~cm}$ üzerindeyse ilk tercih adrenalektomidir. Günümüzde adrenal kitlelerin cerrahisi için laparoskopi yaygın olarak kullanılmaktadır. Tarihsel olarak adrenal kitleler için total adrenalektomi uygulanmıştır. Fakat bilateral tutulumu olan feokromasitoma gibi olgular nedeniyle ilk kez parsiyel adrenalektomi gündeme gelmiştir. Günümüzde bilateral olgularda parsiyel adrenalektomi rutin olarak uygulanmakta iken tek taraflı benign lezyonlarda da uygulanması giderek yaygınlaşmaktadır. Bu çalışmada laparoskopik total ve parsiyel adrenalektomi yapmış olduğumuz olguları kısa dönem sonuçlarını sunmayı amaçliyoruz.

Gereç ve Yöntem: Çalışma Ocak 2010-Aralık 2014 tarihleri arasında adrenal kitle nedenli opere edilen hastaların verileri retrospektif olarak taranması ile yapılmıştır. Belitilen tarihler arasında 33 hastanın sürrenal adenoma nedenli ameliyata alındığı görülmüştür. Çalışmaya dahil edilme kriterlerine uymayan 3 hasta çalışma dışında bırakılmıştır. Çalışmaya dahil edilen 30 hastanın demografik verileri ve yapılan cerrrahi türü hasta dosyalarından öğrenilmiştir. Hastalar kontrole çağırılarak adrenal yetmezlik gelişip gelişmediği ve steroid replasman tedavisi alıp almadıkları sorgulanmıștır.

Bulgular: Çalışmaya alınan 30 hastanın 19’u total adrenalektomi yapıldığı, 11’i parsiyel adrenalektomi yapıldığı görüldü. Total adrenalektomilerinin hepsi unilateral iken parsiyel yapılan ameliyatların 7’si unilateral parsiyel 4’ü bilateral parsiyel adrenalektomi yapılmış olduğu görüldü. Total adrenalektomi yapılan hastaların postoperatif dönemde 3'ünde adrenal yetmezlik gelişirken unilateral parsiyel ve bilateral parsiyel adrenalektomi yapılan hasta gruplarınında birer hastada adrenal yetmezlik geliștiği görüldü.

Sonuçlar: Parsiyel adrenalektomi bilateral olgularda \%75 oranında adrenal yetmezlikten korumuştur. Tek taraflı lezyonlarda da nüks, yetmezlik ve peroperatif komplikasyonlar açısından parsiyel ile total arasında fark yoktur. LPA öğrenme eğrisi tamamlandıktan sonra güvenle uygulanabilir. Bilateral adrenalektomi yapılan hastaların çoğunu yetmezlikten korur. Tek taraflı lezyonlarda uygulaması kolay ve hastaya bir zarar vermediği gibi muhtemel faydaları olaçağına inanıyoruz.

Anahtar Kelimeler: Parsiyel adrenalektomi, korteks koruyucu adrenalektomi, adrenal yetmezlik 


\section{INTRODUCTION}

Adrenal masses were first introduced in 1865 (1). The adrenal gland, which weighs around 4-5 grams and secretes hormones, is found in the upper pole of both kidneys. They consist of two main layers, cortex and medulla. The cortex layer produces aldosterone, cortisol, and androgen hormones, while the medulla layer produces adrenaline and noradrenaline. Depending on which layer of the gland the mass originates from, the symptoms of an adrenal mass vary. The most common adrenal diseases are Cushing's syndrome, Conn's syndrome, and pheochromocytoma. According to the literature, the prevalence of these diseases is 2.3 per million for Cushing's syndrome, 0.2 for Conn's syndrome, and 2-8 for pheochromocytoma $(2,3)$. When masses that develop in the adrenal gland do not cause symptoms, they can sometimes be detected incidentally. On the other hand, in incidentalomas, the incidence of adrenal mass seen in autopsy studies was found to be $2 \%$ on average (4). However, rates between 1-9\% have been reported in different studies. The most frequently treated functional adrenal tumors today are adrenocortical tumors, that secrete excess cortisol, pheochromocytoma, and aldosteronoma. 94\% of adrenal masses are benign, $90 \%$ are non-functional and $80 \%$ are smaller than $2 \mathrm{~cm}$ in diameter. The incidence of malignant adrenal tumors has been reported as $2.7 \%$, and their diameters are generally over $5 \mathrm{~cm}$ (5). For most adrenal masses that present with a variety of symptoms, adrenalectomy is the first treatment option. The first adrenalectomy was performed in 1889 as a result of surgical advancements (6). Adrenaloctomies were always performed with open surgery from this point until 1992. However, Dr. Gagner described laparoscopic adrenalectomy in 1992 (7). Since then, the rate of laparoscopic adrenalectomy has increased and has become the gold standard (8). In earlier publications, malignancy and large adrenal adenomas were indicated as contraindications for laparoscopic adrenal surgery (8-10). In recent studies, it is stated that laparoscopic adrenalectomy is safe in adrenocortical cancers up to $10 \mathrm{~cm}$ in size (11-13). In case of suspected malignancy in adrenal masses, open surgery is recommended. It is well recognized that total adrenalectomy, which is commonly recommended to treat adrenal masses, may result in postoperative adrenal insufficiency $(14,15)$. For this reason, the partial adrenalectomy concept has been introduced.

The aim is to leave sufficient healthy adrenal tissue in the postoperative period to prevent patients from developing adrenal insufficiency and to make them steroidindependent. This study aims to see whether partial adrenalectomy protects against adrenal insufficiency by retrospectively comparing the postoperative outcomes of patients who had total or partial adrenalectomy in our clinic for different reasons.

\section{MATERIAL AND METHOD}

The study was initiated with the approval of the Ankara Atatürk Training and Research Hospital Ethics Committee (Date: 2014, Decision no: 87). All procedures were performed adhered to the ethical rules and principles of the Helsinki Declaration.

In our study, the data of 33 patients who were operated on due to adrenal mass in Ankara Etlik Training and Research Hospital and Ankara Atatürk Training and Research Hospital General Surgery Clinics between January 2010 and December 2014 were retrospectively analyzed. Patients who did not have adrenal insufficiency at the time of admission were included in the study. Three patients who did not want to participate in the study, who did not want to share their information, and who had a suspicion of preoperative malignancy (liver invasion with imaging methods) were excluded from the study.

The demographic data, body mass index (BMI), symptoms at the time of admission, blood tests, and pathology results of the patients included in the study were taken from the hospital database. The information that could not be accessed from the database was obtained by calling the patients for control or by phone call. The symptoms of the patients were grouped. Incidentally detected patients were recorded as asymptomatic. The patients' preoperative definitive diagnoses were validated by reviewing their endocrine consultation notes.

The operation time, type of surgery, hospitalization times, and pathologies of the patients were obtained from the hospital information technology system. Data were compared in the total adrenalectomy and partial adrenalectomy groups.

\section{RESULTS}

Thirty patients who were operated for adrenal mass between January 2010 and December 2014 were included in the study. The gender of the patients was $33.3 \%(n=10)$ male and $66.6 \%(n=20)$ female. The mean age of the patients was $44.7 \pm 6.8$ (min:18-max:67) years, and the BMI was 29.5. When the localization of the masses was examined, it was seen that $50 \%(n=15)$ were located in the right adrenal, $33.3 \%(\mathrm{n}=10)$ were located in the left adrenal and $16.6 \%(n=5)$ were located bilaterally. The symptoms of the patients are presented in Table 1.

\begin{tabular}{|lccccc|}
\hline Table 1. Symptoms during admission & & & \\
\hline Symptoms & M (n) & \% & F (n) & \% & N \\
\hline Headache & 2 & 25 & 6 & 75 & 8 \\
Hypertension & 5 & 29 & 12 & 71 & 17 \\
Palpitation & 2 & 28.6 & 5 & 71.4 & 7 \\
Weight gain & 1 & 14.2 & 6 & 85.8 & 7 \\
Abdominal pain & 2 & 25 & 6 & 75 & 8 \\
Flushing & 2 & 50 & 2 & 50 & 4 \\
Sweating & 1 & 33.3 & 2 & 66.6 & 3 \\
\hline
\end{tabular}


When the procedures performed were examined, it was seen that $63.3 \%(n=19)$ of the patients had unilateral total adrenalectomy, $23.3 \%(n=7)$ of the patients unilateral cortex-sparing (partial) adrenalectomy, and $13.3 \%(\mathrm{n}=4)$ of the patients had bilateral cortex-sparing (partial) adrenalectomy (Table 2).

\begin{tabular}{|lccccc|}
\hline Table 2. Surgery type & Right & $\begin{array}{c}\text { Left } \\
\text { Operation }\end{array}$ & $\begin{array}{c}\text { Right } \\
\text { cortex } \\
\text { adrenalectomy }\end{array}$ & $\begin{array}{c}\text { Left } \\
\text { cortex } \\
\text { sparing }\end{array}$ & $\begin{array}{c}\text { Bilateral } \\
\text { sortex } \\
\text { sparing }\end{array}$ \\
\hline Total & 13 & 6 & 4 & 3 & 4 \\
\hline
\end{tabular}

The rate of conversion to open surgery between the groups was $10.5 \%(n=2)$ in the Total Adrenalectomy group and 27\% (3) in the Partial Adrenalectomy group, but it was not statistically significant (Table 3) $(\mathrm{p}=0.326)$. The overall rate of conversion to open surgery was $16.6 \%$ $(n=5)$ in 30 patients included in the study. Duration of hospitalization was 3.5 days on average in the total adrenalectomy group, whereas it was 3.2 in the partial adrenalectomy group.

\begin{tabular}{|c|c|c|c|}
\hline & $\begin{array}{c}\text { Total } \\
\text { adrenalectomy } \\
(\mathrm{n}=19)\end{array}$ & $\begin{array}{c}\text { Partial } \\
\text { adrenalectomy } \\
(n=11)\end{array}$ & \\
\hline Laparoscopic & 17 & 8 & \multirow[b]{2}{*}{$\mathrm{p}=0.326$} \\
\hline $\begin{array}{l}\text { Converted to } \\
\text { open surgery }\end{array}$ & 2 & 3 & \\
\hline $\begin{array}{l}\text { Operation times } \\
\text { (min.) }\end{array}$ & 126.8 & 145.4 & \\
\hline
\end{tabular}

Considering the mean operation times, the mean duration of partial adrenalectomy was 145.4 minutes, while the mean surgical time in total adrenalectomy was 126.8 minutes. It was observed that the mean follow-up period of the patients was 24.5 months (min: 7, max: 55). During long-term (6 months) follow-up, 5 patients were found to have adrenal insufficiency. Adrenal insufficiency was observed in $15.7 \%(n=3)$ of patients who underwent unilateral total adrenalectomy, $14.2 \%(\mathrm{n}=1)$ of patients who underwent unilateral partial adrenalectomy, and $25 \%(\mathrm{n}=1)$ of patients who underwent bilateral partial adrenalectomy. It was observed that all patients diagnosed with Cushing's syndrome before surgery were applied the standard Addison protocol in the postoperative period.

No recurrence was detected in the follow-up of the patients.

\section{DISCUSSION}

The incidence of adrenal masses in the population is less than $1 \%$. However, symptomatic adrenal masses impair a person's quality of life and must be treated. Most of the adrenal masses are treated surgically (16). In this study, it was discovered that only 30 patients with adrenal mass were operated on in general surgery clinics of two hospitals (Ankara Atatürk Training and Research Hospital and Ankara Etlik Training and Research Hospital) over 5 years, even though the clinic conducted an average of 20 operations per day. Laparoscopic adrenalectomy is advantageous in terms of morbidity, patient comfort, and hospital stay (17). But surgeons should select the surgical method in which they are most experienced and trained, to be able to obtain the best results considering the risk factors (19). All of the patients included in this study were operated on laparoscopically, but due to bleeding, 5 of the 30 cases were moved to open surgery. When we examine the various case series in the literature, the rate of conversion to open surgery varies between $2.2-6.9 \%$ (18-20). When compared with the literature, it is seen that the rate of conversion to open surgery is high in this study. The majority of literature publications come from reference centers. As a natural consequence of this, in a center where all general surgery cases are performed, the rate of conversion to open surgery is higher.

Until recently, adrenal masses were treated with a unilateral or bilateral total adrenalectomy, regardless of their size or characteristics. However, even though a patient has unilateral adrenalectomy, they can develop adrenal insufficiency (21). The explanation for this is that in Cushing's syndrome, the contralateral adrenal gland is suppressed due to an adenoma with elevated cortisol release (22). Adrenal insufficiency is a common symptom in pheochromocytoma patients who have had bilateral adrenalectomy (23). Adrenal insufficiency is a life-threatening condition due to cortisol deficiency. It also impairs the person's quality of life. Symptoms of adrenal insufficiency are generally unwellness of the patient, nausea, loss of appetite, vomiting, abdominal pain, and loss of consciousness (22-23). In $85-90 \%$ of patients, hyponatremia and hyperkalemia are present. Patients often apply to the emergency room with crisisrelated shock (24). In a study, $35 \%$ of patients were admitted to the hospital with adrenal crisis following bilateral adrenalectomy, with a $3 \%$ mortality rate (15). In a recently published meta-analysis, it was reported that $10-35 \%$ of patients experienced adrenal insufficiency after adrenalectomy (25). Patients who develop adrenal insufficiency can become steroid dependent for the rest of their lives. Therefore, the definition of partial adrenalectomy, or cortex-sparing adrenalectomy, as it is known in the literature, was introduced in 1983 by Dr. 
Irvin et al. (26) The first studies on laparoscopic partial adrenalectomy were conducted in 1996 by Dr. Lee et al. (27) Following this, laparoscopic partial adrenalectomy was described in 1997 for an aldosterone-secreting adenoma (28). The aim here is to protect the patient from adrenal insufficiency and reduce steroid addiction by preserving healthy adrenal tissue. It is recommended that more than one-third of the adrenal gland be left to maintain adrenal functions $(29,30)$. In this study, this rule was found to be followed in the surgical technique of patients who underwent partial adrenalectomy. Of the 30 adrenal mass cases, which were the subject of our study over a 5 years, $19(63.3 \%)$ were operated as total adrenalectomy and $11(32.7 \%)$ as partial adrenalectomy (Figure 1). It is the gold standard in masses such as bilateral pheochromocytoma, but should cortexsparing (partial) adrenalectomy be performed in unilateral adrenal masses? Even if total adrenalectomy is performed unilaterally, studies have shown that adrenal insufficiency may grow $(31,32)$. It is currently unclear in which patient has the indication for partial adrenalectomy. However, partial adrenalectomy may be performed for unilateral or bilateral masses that do not appear to be malignant on radiology and are less than $4 \mathrm{~cm}$ in size, according to studies in the literature $(33,34)$. Partial adrenalectomy can be easily performed, particularly in adenomas secreting aldosterone $(35,36)$. Because the aldosteronoma cases typically appear as small solitary masses.

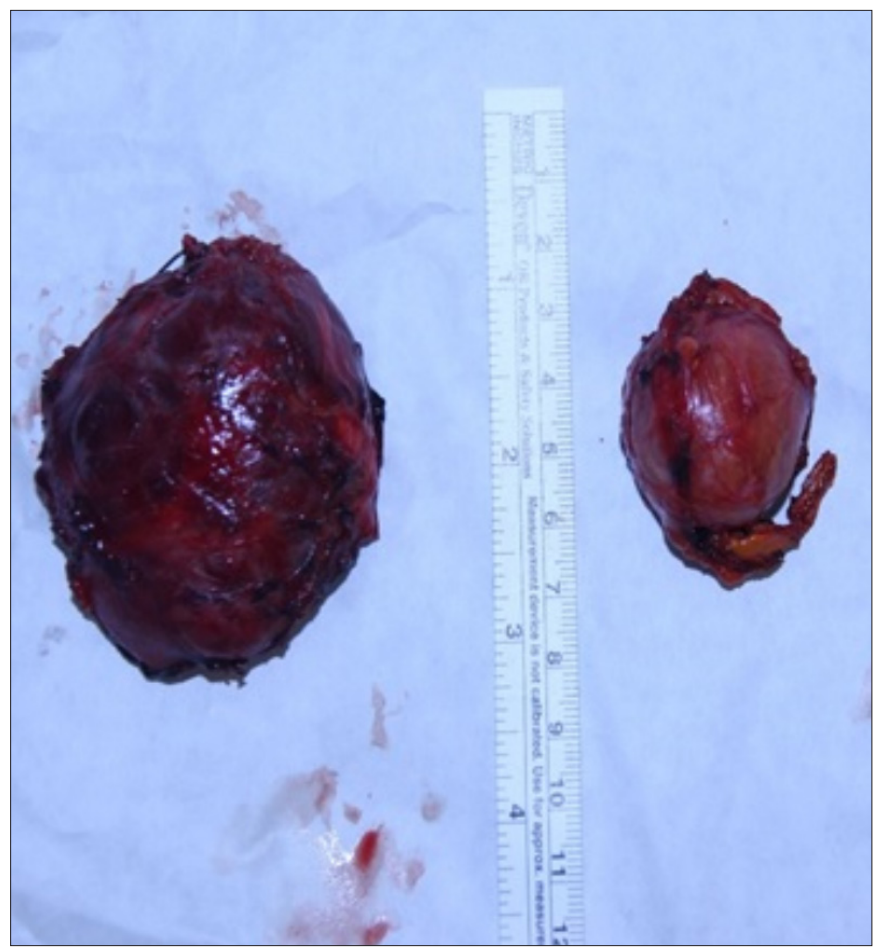

Figure. Bilateral cortex sparing adrenalectomy for pheochromocytoma
When we examine the preoperative diagnoses of 19 patients who underwent total unilateral adrenalectomy, it was observed that there were 8 Cushing, 2 Conn, 5 pheochromocytomas, and 4 incidentaloma cases. Adrenal insufficiency occurred in $3(15.7 \%)$ of patients who underwent unilateral adrenalectomy in the postoperative period, necessitating steroid replacement therapy. When we examined the diagnoses of patients who experienced adrenal insufficiency after unilateral adrenalectomy, we discovered that they all had Cushing syndrome. Since the pituitary-adrenal axis is suppressed due to cortisol secreting adenoma in these patients, adrenal insufficiency may prevail in the postoperative period (31). This rate has been reported to vary between $12-17 \%$ in various studies in the literature Findings obtained in our study also support this ratio. The patient's steroid addiction fades with the normal function of the suppressed contralateral adrenal tissue. It takes an average of 10 to 25 months for the contralateral adrenal gland to become fully functional $(31,32)$. The treatment period of our unilateral total adrenalectomy patients who developed adrenal insufficiency varies between 10-29 months. It was observed that 2 of these 3 patients presented to the emergency department due to an adrenal insufficiency crisis during their follow-up, while steroid replacement therapy was continuing. It is very difficult to adjust the steroid dose in patients presenting with adrenal insufficiency. Furthermore, in stressful conditions, the standard dosage may be insufficient, and patients can develop adrenal insufficiency (37).

The preoperative diagnosis of all patients who underwent bilateral partial adrenalectomy was pheochromocytoma. The diagnosis of 3 of our patients who underwent partial unilateral adrenalectomy was pheochromocytoma, 2 patients were diagnosed with aldosterone-secreting adenoma, and 2 patients were diagnosed with cortisolsecreting solitary adenoma. Adrenal insufficiency developed in 1 of the patients who underwent unilateral partial adrenalectomy.

One of the patients who had bilateral partial adrenalectomy also developed adrenal insufficiency. Adrenal insufficiency can be seen in $35 \%$ of patients who underwent bilateral total adrenalectomy despite replacement therapy (15). Despite the small number of cases in our study, the fact that only 1 patient required steroid replacement therapy due to adrenal insufficiency during the 24.5-month follow-up period indicates that partial adrenalectomy is a viable option. It was observed that adrenal insufficiency developed in 1 of 7 unilateral partial adrenalectomy cases performed in our clinic in the postoperative period. This ratio is seen to be high compared to previous studies. However, this patient is also a patient who underwent partial adrenalectomy due 
to Cushing's syndrome. As previously stated, we believe this patient requires steroid replacement therapy because the residual adrenal tissue is suppressed.

In the studies performed, no difference was found between partial and total adrenalectomy in terms of the operation time, bleeding amount, and morbidity $(29,36)$. Considering the mean operation times, the mean duration of partial adrenalectomy was 145.4 minutes, while the mean surgical time in total adrenalectomy was 126.8 minutes. Studies have reported that partial adrenalectomy can take up to 130 (37-560) minutes depending on the number of cases and the clinic's experience (34), (38). Although there was no significant difference in operation times in literature studies, we can attribute the difference found in our study to the higher rate of conversion to open surgery in partial adrenalectomy. While our rate of conversion to open surgery in partial adrenalectomy was $27 \%$, this rate was found to be $10.5 \%$ in total adrenalectomy. The high duration of our operation compared to the literature can be attributed to the fact that we have not yet completed the learning period. In the studies conducted, a significant decrease was observed in the operation times after the first 50 cases (29).

When partial adrenalectomy is compared to total adrenalectomy, studies indicate that there is no difference in terms of recurrence and that it decreases the need for steroid replacement therapy in long-term follow-up (29). In this study, no recurrence was detected in any of the patients as well.

\section{CONCLUSION}

There is no difference between partial and total adrenalectomy in terms of recurrence, insufficiency, and perioperative complications. After the learning curve has been completed, LPA can be used safely. It protects most patients who undergo bilateral adrenalectomy from adrenal insufficiency. In addition to being easy to apply in unilateral lesions and not causing any harm to the patient, we think that it will have possible benefits.

\section{ETHICAL DECLARATIONS}

Ethics Committee Approval: The study was initiated with the approval of the Ankara Atatürk Training and Research Hospital Ethics Committee (Date: 2014, Decision No: 87).

Informed Consent: Because the study was designed retrospectively, no written informed consent form was obtained from patients.

Referee Evaluation Process: Externally peer-reviewed.

Conflict of Interest Statement: The authors have no conflicts of interest to declare.
Financial Disclosure: The authors declared that this study has received no financial support.

Author Contributions: All of the authors declare that they have all participated in the design, execution, and analysis of the paper, and that they have approved the final version.

Acknowledgement: Our research's data was presented in 19. National Surgical Congress as 'Oral Presentation' on April 2014.

\section{REFERENCES}

1. Courtney T, Beauchamp RD, Evers BM, et al. 'Adrenal Gland Chapter 8, in Sabiston Textbook of Surgery : The Biological Basis of Modern Surgical Practice, 17th ed. (June 11, 2004)

2. Takayanagi R, Miura K, Nakagawa H, Nawata H. Epidemiologic study of adrenal gland disorders in Japan. Biomed Pharmacother 2000; 54: 164-8.

3. Lindholm J, Juul S, Jørgensen JO, et al. Incidence and late prognosis of cushing's syndrome: a population-based study. J Clin Endocrinol Metab 2001; 86: 117-23.

4. Terzolo M, Stigliano A, Chiodini I, et al. AME position statement on adrenal incidentaloma. Eur J Endocrinol 2011; 164: 851-70.

5. Prager G, Heinz-Peer G, Passler C, et al. Surgical strategy in adrenal masses. Eur J Radiol 2002; 41: 70-7.

6. Richard B. Welbourn, Stanley R. et al. 'The History of Endocrine Surgery by-Praeger-ABC-CLIO'. https: //products.abc-clio.com/abccliocorporate/product.aspx?pc=C9005C (accessed May 23, 2021).

7. Gagner M, Lacroix A, Bolté E. Laparoscopic adrenalectomy in Cushing's syndrome and pheochromocytoma. N Engl J Med 1992; 327: 1033.

8. Ip JCY, Lee JC, Sidhu SB. Laparoscopic adrenalectomy: the transperitoneal approach. Curr Surg Rep 2013; 1: 26-33.

9. Schteingart DE, Doherty GM, Gauger PG, et al. Management of patients with adrenal cancer: recommendations of an international consensus conference. Endocr Relat Cancer 2005; 12: 667-80.

10. Prager G, Heinz-Peer G, Passler C, Kaczirek K, Scheuba C, Niederle B. Applicability of laparoscopic adrenalectomy in a prospective study in 150 consecutive patients. Arch Surg 2004; 139: 46-9.

11.Prager G, Heinz-Peer G, Passler C, Kaczirek K, Scheuba C, Niederle B. Applicability of laparoscopic adrenalectomy in a prospective study in 150 consecutive patients. Arch Surg 2004; 139: 46-9.

12. Brix D, Allolio B, Fenske W, et al. Laparoscopic versus open adrenalectomy for adrenocortical carcinoma: surgical and oncologic outcome in 152 patients. Eur Urol 2010; 58: 609-15.

13. McCauley LR, Nguyen MM. Laparoscopic radical adrenalectomy for cancer: long-term outcomes. Curr Opin Urol 2008; 18: 134-8.

14. Porpiglia F, Fiori C, Daffara F, et al. Retrospective evaluation of the outcome of open versus laparoscopic adrenalectomy for stage I and II adrenocortical cancer. Eur Urol 2010; 57: 873-8.

15. Neumann HP, Reincke M, Bender BU, Elsner R, Janetschek G. Preserved adrenocortical function after laparoscopic bilateral adrenal sparing surgery for hereditary pheochromocytoma. J Clin Endocrinol Metab 1999; 84: 2608-10.

16. Asari R, Scheuba C, Kaczirek K, Niederle B. Estimated risk of pheochromocytoma recurrence after adrenal-sparing surgery in patients with multiple endocrine neoplasia type 2A. Arch Surg 2006; 141: 1199-205.

17. 'Adrenalectomy, Open And Minimal invazive', in Mastery of Surgery, Fifth Edition, 5th ed., 2011; pp. 458-62.

18. Elfenbein DM, Scarborough JE, Speicher PJ, Scheri RP. Comparison of laparoscopic versus open adrenalectomy: results from American College of Surgeons-National Surgery Quality Improvement Project. J Surg Res 2013; 184: 216-20. 
19.Durhan A , Süleyman M . Evaluation of the clinical indications and surgical methods in patients who underwent adrenalectomy. Ankara Eğitim ve Araştırma Hastanesi Tip Derg 2021; 54: 117-22.

20. Kazaryan AM, Marangos IP, Rosseland AR, et al. Laparoscopic adrenalectomy: Norwegian single-center experience of 242 procedures. J Laparoendosc Adv Surg Tech A 2009; 19: 181-9.

21. Tatsugami K, Eto M, Hamaguchi M, Yokomizo A, Harano M, Naito S. What affects the results of a laparoscopic adrenalectomy for pheochromocytoma? Evaluation with respect to intraoperative blood pressure and state of tumor. J Endourol 2009; 23: 101-5.

22. Higashihara E, Baba S, Nakagawa K, et al. Learning curve and conversion to open surgery in cases of laparoscopic adrenalectomy and nephrectomy. J Urol 1998; 159: 650-3.

23. Kazama I, Komatsu Y, Ohiwa T, Sanayama K, Nagata M. Delayed adrenal insufficiency long after unilateral adrenalectomy: prolonged glucocorticoid therapy reduced reserved secretory capacity of cortisol. Int J Urol 2005; 12: 574-7.

24. Di Dalmazi G, Berr CM, Fassnacht M, Beuschlein F, Reincke M. Adrenal function after adrenalectomy for subclinical hypercortisolism and Cushing's syndrome: a systematic review of the literature. J Clin Endocrinol Metab 2014; 99: 2637-45.

25. Hawn MT, Cook D, Deveney C, Sheppard BC. Quality of life after laparoscopic bilateral adrenalectomy for Cushing's disease. Surgery 2002; 132: 1064-9.

26. DeFronzo RA. Hyperkalemia and hyporeninemic hypoaldosteronism. Kidney Int 1980; 17: 118-34.

27. Nagaraja V, Eslick GD, Edirimanne S. Recurrence and functional outcomes of partial adrenalectomy: a systematic review and metaanalysis. Int J Surg 2015; 16: 7-13.

28. Irvin GL $3^{\text {rd }}$, Fishman LM, Sher JA. Familial pheochromocytoma. Surgery 1983; 94: 938-40.

29. Lee JE, CurleySA, Gagel RF, Evans DB, Hickey RC. Cortical-sparing adrenalectomy for patients with bilateral pheochromocytoma. Surgery 1996; 120: 1064-71.

30. Janetschek G, Lhotta K, Gasser R, Finkenstedt G, Jaschke W, Bartsch G. Adrenal-sparing laparoscopic surgery for aldosteroneproducing adenoma. J Endourol 1997; 11: 145-8.

31. Walz MK, Peitgen K, Diesing D, et al. Partial versus total adrenalectomy by the posterior retroperitoneoscopic approach: early and long-term results of 325 consecutive procedures in primary adrenal neoplasias. World J Surg 2004; 28: 1323-9.

32. Brauckhoff M, Nguyen Thanh P, Bär A, Dralle H. Subtotale bilaterale Adrenalektomie mit adrenokortikalem Funktionserhalt [Subtotal bilateral adrenalectomy preserving adrenocortical function]. Chirurg 2003; 74: 646-51.

33. Di Dalmazi G, Berr CM, Fassnacht M, Beuschlein F, Reincke M. Adrenal function after adrenalectomy for subclinical hypercortisolism and Cushing's syndrome: a systematic review of the literature. J Clin Endocrinol Metab 2014; 99: 2637-45.

34. Skalkeas G, Gogas JG, Sechas MN, Kostakis A, Pavlatos F. Cushing's syndrome. Analysis of 18 cases. Am J Surg 1982; 143: 363-6.

35.Lal G, Duh QY. Laparoscopic adrenalectomy--indications and technique. Surg Oncol 2003; 12: 105-23.

36. Kaye DR, Storey BB, Pacak K, Pinto PA, Linehan WM, Bratslavsky G. Partial adrenalectomy: underused first line therapy for small adrenal tumors. J Urol 2010; 184: 18-25.

37.Kok KY, Yapp SK. Laparoscopic adrenal-sparing surgery for primary hyperaldosteronism due to aldosterone-producing adenoma. Surg Endosc 2002; 16: 108-11.

38. Jeschke K, Janetschek G, Peschel R, Schellander L, Bartsch G, Henning K. Laparoscopic partial adrenalectomy in patients with aldosterone-producing adenomas: indications, technique, and results. Urology 2003; 61: 69-72.
39. Nambirajan T, Leeb K, Neumann HP, Graubner UB, Janetschek G. Laparoscopic adrenal surgery for recurrent tumours in patients with hereditary phaeochromocytoma. Eur Urol 2005; 47: 622-6.

40. Ishidoya S, Ito A, Sakai K, et al. Laparoscopic partial versus total adrenalectomy for aldosterone producing adenoma. J Urol 2005; 174: 40-3. 